\title{
BEHAVIOR
}

\section{Predatory behavior of three centipede species of the order Scolopendromorpha (Arthropoda: Myriapoda: Chilopoda)}

\author{
Samuel P.G. Guizze', Irene Knysak', Katia C. Barbaro²,

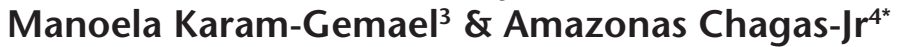

\begin{abstract}
'Laboratório de Artrópodes, Instituto Butantan. Avenida Vital Brasil 1500, 05503-900 São Paulo, SP, Brazil. ${ }^{2}$ Laboratório de Imunopatologia, Instituto Butantan. Avenida Vital Brasil 1500, 05503-900 São Paulo, SP, Brazil. ${ }^{3}$ Programa de Pós-Graduação em Ecologia e Conservação da Biodiversidade, Instituto de Biociências, Universidade Federal de Mato Grosso. Avenida Fernando Correa da Costa 2367, Boa Esperança, 78060-900 Cuiabá, MT, Brazil. ${ }^{4}$ Departamento de Biologia e Zoologia, Instituto de Biociências, Universidade Federal de Mato Grosso. Avenida Fernando Correa da Costa 2367, Boa Esperança, 78060-900 Cuiabá, MT, Brazil.

"Corresponding author. E-mail: amazonaschagas@gmail.com
\end{abstract}

\begin{abstract}
Studies related to centipede feeding and predatory behavior are rare in the literature, and are limited to observations made during fieldwork. Furthermore, they lack descriptions of prey capture. We conducted a laboratory experiment using South American specimens of Scolopendra viridicornis Newport, $1844(n=5)$, Otostigmus tibialis Brölemann, $1902(n=$ 5), and Cryptops iheringi Brölemann, $1902(n=5)$, as well as 13 different kinds of prey, to map and describe their predatory behavior. The analysis of video images (65 hours of recordings) resulted in 15 behavioral categories that describe foraging, prey capture, feeding, and cleaning habits. Almost all observations (95\%) concluded with the centipede killing the prey. Although we witnessed that a stimulus triggered the movement of the centipede toward the prey in all observation events (suggesting a sit-and-wait strategy), our experiments also showed that these arthropods actively forage to seek food. Field observations during the experiment allowed us to document that scolopendromorphs feed on plants when animal prey items are not available. Moreover, we observed that the size and aggressiveness of the prey determined the centipede capture process. Our results revealed that two behavioral categories were performed only by $S$. viridicornis, and thus might be genus or species-specific. These are: raising the first third of the body while the rest of the body remains adjacent to the substrate; and restraining the prey along the ventral region of the first third of the body with the aid of locomotory legs. We also observed some peculiar behaviors performed only by $\mathrm{O}$. tibialis. Our results confirm that $\mathrm{S}$. viridicornis, $\mathrm{O}$. tibialis and $\mathrm{C}$. iheringi hold prey between their ultimate pair of legs.
\end{abstract}

KEY WORDS. Cryptops, ethogram, EthoSeq, Otostigmus, Scolopendra.

Centipedes are terrestrial arthropods with the body divided into a head, and a long segmented trunk bearing one pair of legs per segment. At the level of the ventral region of the head, there is a pair of forcipules with poison glands. These are modified appendages of the first trunk segment, used to capture or kill prey. Centipedes mainly prey on insects, but they are also able to capture small vertebrates, such as lizards, amphibians, rodents, snakes, and even birds and bats (Lewis 1981, Molinari et al. 2005, Srbek-Araujo et al. 2012, Noronha et al. 2015).

More than 3300 species of centipedes, divided into five extant orders, are known from all continents, except Antarctica (Bonato et al. 2016). They have nocturnal habitats and can be found under decaying trunks, on the litter, in subterranean gal- leries, and inside termite mounds. These animals are also found in anthropic areas around (gardens, under bricks, among rubble) and inside houses (in dark and damp rooms).

Representatives of the order Scolopendromorpha, with about 800 species, include the largest, most aggressive and perhaps most frequently noticed centipedes. The species belonging to the genus Scolopendra Linnaeus, 1758 are responsible for most of the accidents involving people around the world. In Brazil, the centipedes belonging to the genera Scolopendra, Cryptops Leach, 1815 and Otostigmus Porat, 1876 account for most incidents involving humans (KNYSAK et al. 1994, 1999, Medeiros et al. 2008).

Studies on the feeding habits and breeding behavior of centipedes are rare in the literature, and are restricted to field 
observations. The available reports, which do not describe prey capture but point to an active foraging behavior, present records of centipedes preying on birds in their nests (Cumming 1903), small mammals (CLoudsLey-Thompson 1958, Molinari et al. 2005, Srbek-Araujo et al. 2012, Noronha et al. 2015), reptiles and amphibians (OKEDEN 1903, CARPENTER \& GIllingham 1984), insects and invertebrates (CloudsLey-Thompson 1955), and even compound foods and fruits (Misra 1942, MANTON 1964).

Therefore, the objective of this study is to map and describe the predatory behavior of three species of South American scolopendromorph centipedes held in captivity by identifying and describing the sequence of movements during predation.

\section{MATERIAL AND METHODS}

Fifteen specimens belonging to three species of Scolopendromorpha from South America were selected for the experiment: S. viridicornis $(\mathrm{n}=5), C$. iheringi $(\mathrm{n}=5)$, and O. tibialis $(n=5)$ (see Figs. 1-3). The body length of individuals of each species ranged between 200-250 mm, 100-120 mm, and 70-80 $\mathrm{mm}$, respectively. The animals were kept in $450 \times 210 \times 250$ $\mathrm{mm}$ and $320 \times 150 \times 200 \mathrm{~mm}$ glass terrariums covered with a screen. The terrariums had sand as substrate and coconut fiber vessels for shelter. Water was supplied in cotton inside $90 \mathrm{x}$ $15 \mathrm{~mm}$ glass containers. Centipedes were kept in a room with inverted photoperiod, with active illumination for 12 hours per day, at the Arthropods Laboratory of the Instituto Butantan (São Paulo, Brazil).

The diet provided during the experiment aimed to encompass a wide variety of prey: cockroaches (Blaberus sp., Periplaneta americana Linnaeus, 1758, Pycnoscelus surinamensis (Linnaeus, 1758), and Blaberidae Saussure, 1864); larvae and adult beetles of Zophobas morio Fabricius, 1776; spiders of the infraorder Araneomorphae (Lycosa erythrognatha Lucas, 1836) and Mygalomorphae (Acanthoscurria sp.); newborn mice (Mus musculus domesticus Schwarz \& Schwarz, 1943) (10 g); amphibians (Rhinella crucifer Wied-Neuwied, 1821); snakes (Liophis typhlus (Linnaeus, 1758) and Sibynomorphus mikanii (Schlegel, 1836)); and earthworms (Lumbricus rubellus Hoffmeister, 1843).

One specimen of each prey type was offered directly to each one of five individual centipedes, reaching a total of 65 observation events (both larvae and adults of $Z$. morio were offered, amounting to 13 different kinds of prey). Feeding was provided to each centipede at 15-day intervals, always in a period without light. If the centipede would not capture the prey offered during the experiment, another (previously offered) resource was offered at the same day, to maintain feeding periodicity, since different periods of starvation could lead to different responses.

Predatory behavior was recorded with an HI 8 Sony camera, which has a night-shot function to record images in darkrooms. Each observation event lasted one hour and was initiated by an eliciting stimulus (O) (a triggering stimulus of a behavioral sequence, usually caused by vibrations, chemical
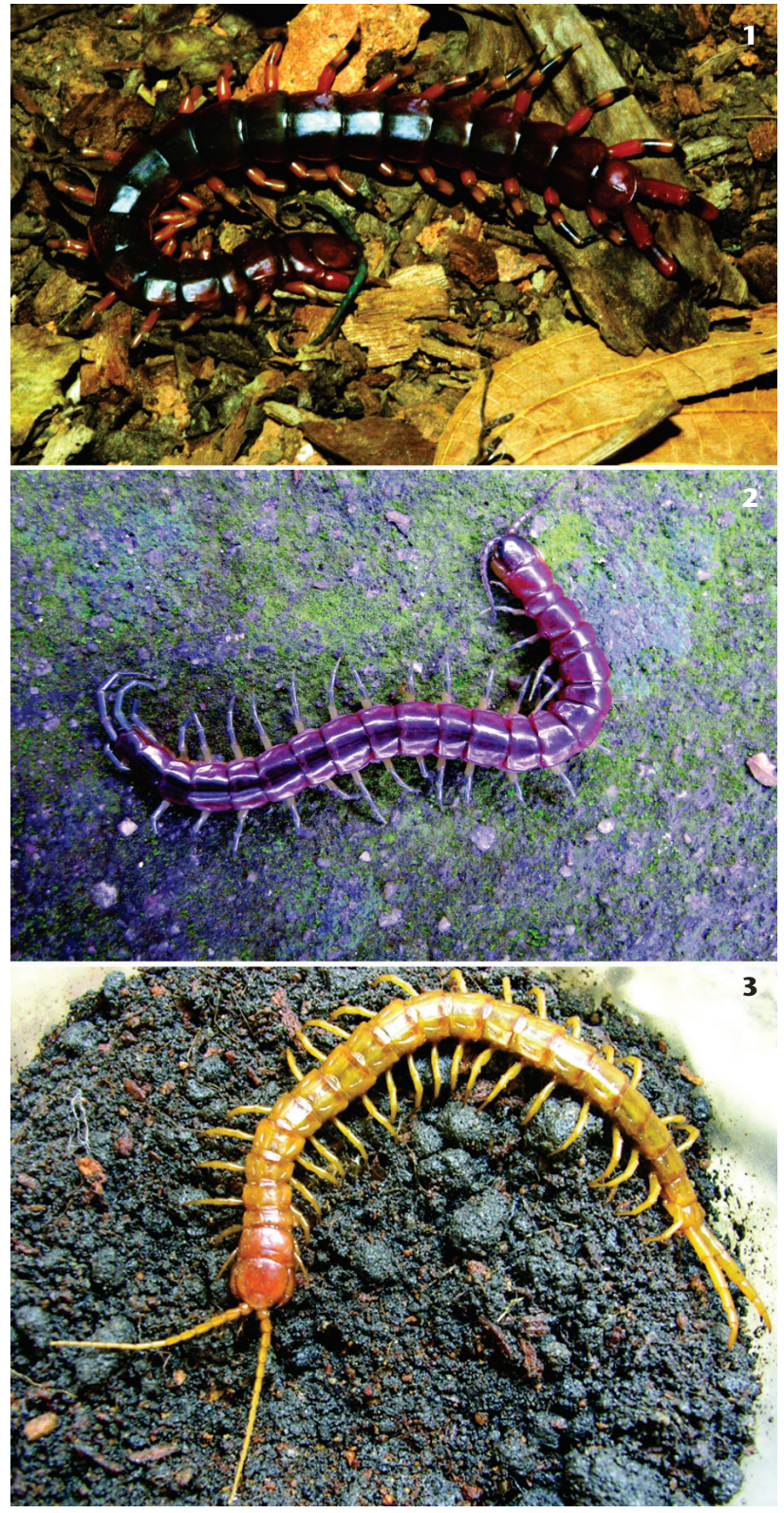

Figures 1-3. Species of Scolopendromorpha used for the experiments of predatory behavior mapping and description: (1) Scolopendra viridicornis; (2) Otostigmus tibialis; (3) Cryptops iheringi.

residues left in the air or substrate, or even the direct touch of the prey on the centipede).

Predatory sequences were considered successful when they ended up with the prey being captured and killed. Predatory behavior was categorized through the analysis of recordings, and data was analyzed with EthoSeq software (JAPYASSú et al. 2006) on drawings of ethograms. 


\section{RESULTS}

Of the 65 observations, 62 were considered successful and led to slaughter of the prey by the centipede. All predatory sequences (including three in which the prey was not captured) were included in the analysis and were used to generate ethograms. The behavioral categories of predation by centipedes, as determined in this study, are listed below.

Antennal movement $(\mathrm{M})$ - the extended antennae are raised and lowered repeatedly without touching the substrate or the prey. Groping the substrate (Ts) - the extended antennae are raised and lowered to touch the ground repeatedly during locomotion or when stationary. This category differs from the antennal movement (M), as groping the substrate does not include antennal movements in air. In this category the antennae always touch the ground during movement. Groping the prey (Tp) - antennae are raised and lowered to touch the prey. The movement can be repeated and is followed by onslaught (I). Posture 1 (X1) - after an eliciting stimulus (O), the centipede vertically raises the ultimate pair of legs. The elevation angle is directly proportional to the intensity of the stimulus. Raising (E) - centipede raises the first third of the body as the rest of the body remains adjacent to the substrate. This behavioral category may be associated with locomotion (Ç). Capture (C) - insertion of forcipules into prey. Containment $(\mathrm{G})$ - prey restraint along the ventral region of the first third of the body, with the aid of locomotory legs. Legs of other segments are used as anchorage in the substrate. Onslaught (I) - displacement of the centipede toward the prey faster than the speed used in locomotion. Pinch (P) - lateral movement of the head and ultimate pair of legs simultaneously converging toward the prey. Transport (S) - the centipede restrains the prey along the ventral region of the first third of the body, assumes the raising posture (E), and moves to another area of the terrarium. Feeding (A) - scraping movement of mouthparts on the prey. Scissor $(\mathrm{Z})$ - prey restraint with the ultimate pair of legs. Locomotion (Ç) - orderly movement of the legs, in which the animal's body is kept above ground and moves toward a certain direction. Antennae cleaning (La) - scraping movement of mouthparts on the antennae (from base to distal end). Body cleaning (Lc) - scraping movement of mouthparts along the body and legs (from base to distal ends), the head is then cleaned by scraping legs 1-4 of the body segment.

An ethogram was drawn from observations of behavioral sequences of centipedes during the experiment (see Fig. 4).

Centipedes only started a movement toward the prey upon receiving an eliciting stimulus $(\mathrm{O})$ in all observation events. After the stimulus, locomotion toward prey is associated with vertical movements of the antennae, sometimes groping the ground or lightly touching the prey (M, Ts, Tp), until the containment action $(\mathrm{G})$.

The scissor action $(\mathrm{Z})$ is induced when the prey touches the ultimate pair of legs. When it touches the middle region of the trunk $\left(9^{\text {th }}-18^{\text {th }}\right.$ segment) the pinching movement $(\mathrm{P})$ is

\section{Prey stimulus on the} centipede

(0)

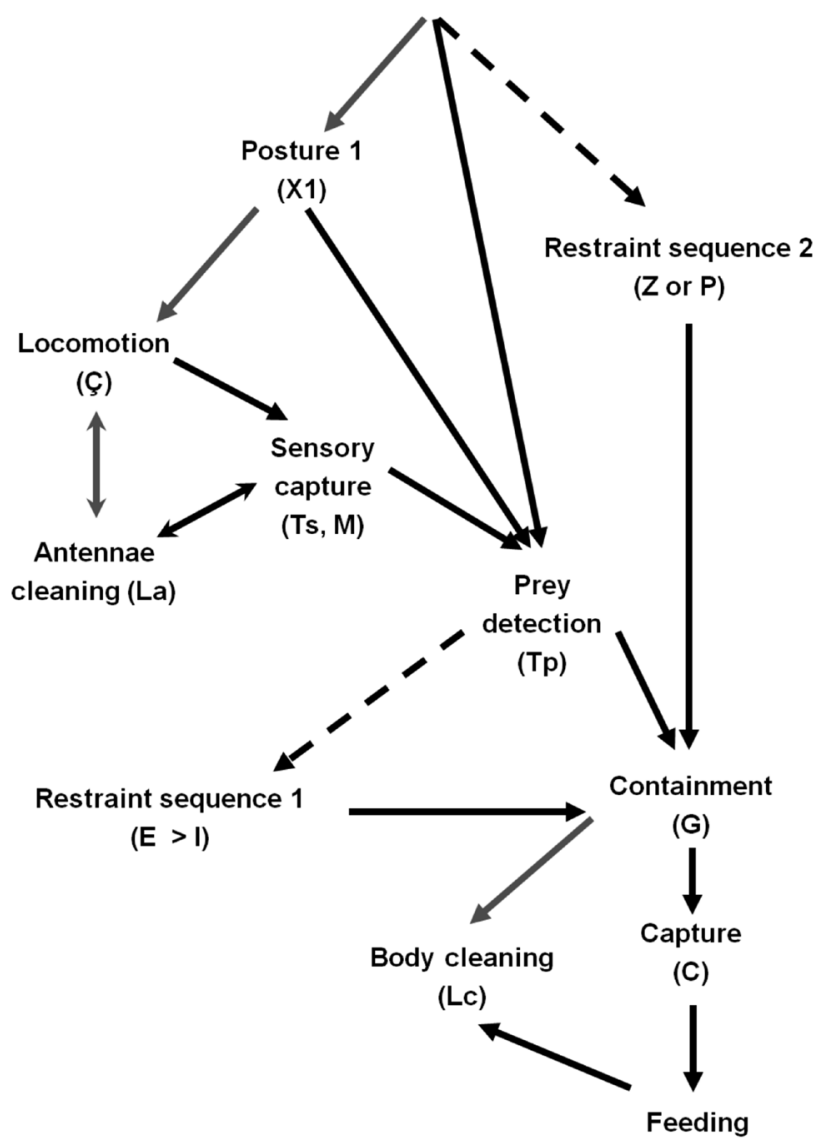

Behavioral category transition frequency

(A)

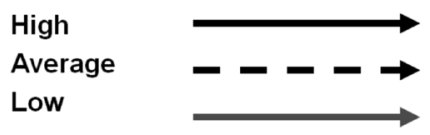

Figure 4. Ethogram of behavioral sequences of predation by centipedes (Scolopendra viridicornis, Otostigmus tibialis, and Cryptops iheringi specimens) observed during experiments of predatory behavior mapping and description; Containment behavioral category (G) is exclusive of S. viridicornis.

commonly induced. Containment $(\mathrm{G})$ is extremely fast and may exhibit wide variation among behavioral categories. It may be followed by manipulation and/or prey transport (S). Cylindrically shaped prey (insect larvae, snakes, and annelids) were usually captured (C) with forcipule insertion on the posterior portions of the body.

All specimens showed the same behavior while groping the substrate (Ts). We observed a few seconds of antenna 
cleaning (La) during this action. Then, the animals returned to foraging or to resting condition. After prey containment $(G)$ or the beginning of the feeding process (A), centipedes sometimes transported (S) the prey to a shelter. The centipedes ignored vertebrate bone remains or strongly chitinized insects. Scolopendra viridicornis does not wait until the prey stops moving to begin the feeding process (A) and holds the resources using its locomotory legs ( $1^{\text {st }}-15^{\text {th }}$ segment) $(G)$.

Although centipedes detected the specimens of $R$. crucifer in all five observations involving this prey, only two individuals were captured (C). One of them was abandoned right after its parotoid gland was drilled. After touching the gland, the centipede started body cleaning (La and Lc) associated with friction of mouthparts and the cephalic plate against the substrate. The second specimen captured was fully consumed. The same cleaning process was observed after predation of annelids.

Among all different species of prey offered in the experiment, we observed that the size and aggressiveness of the prey (mice, spiders and snakes) are determinants of the capture process by centipedes. The large body and aggressive defense behavior of tarantulas prevented a second predation attempt by two of the five specimens of $S$. viridicornis.

Observations during the regular feeding of animals in captivity showed that the specimens of $S$. viridicornis foraged actively. It detected and fed on inert foods like raw meat fragments, dog food pellets, compound foods (chocolate, cheese bread, and milk pudding), and even fruits (apple, banana, pear), as also reported by LewIs (1981).

The predatory behavior of $O$. tibialis and $C$. iheringi is strongly similar to $S$. viridicornis, except for the containment $(\mathrm{G})$ and raising (E) categories (see Table 1). Otostigmus tibialis and C. iheringi individuals used only the forcipules to capture and contain prey.
While foraging, locomotion (Ç) and antennal movements (Ts, $\mathrm{M}$ and Tp) were more frequent in the behavior of specimens of $C$. iheringi. Posture 1 (X1) was associated with a quick lateral sequential movement of the ultimate pair of legs.

Otostigmus tibialis, known for its fossorial habits, showed a clear differentiation in predatory behavior. Despite the lodging of specimens in underground galleries, which hampered detailed view, we observed peculiar actions by the representatives of this species: (i) the animal keeps the first third of the body housed inside the gallery during the scissor behavior (Z); (ii) the behavioral sequence onslaught (I)/capture (C) starts inside the gallery, where the centipede remains with antennae on the outside, close to the ground; (iii) after the touch of prey with the antennae $(\mathrm{O})$, the centipede invests $(\mathrm{I})$, captures $(\mathrm{C})$, and carries (S) prey into the gallery.

\section{DISCUSSION}

The description of the behavioral category of scissoring (Z) supports the observations by SCHILEYKo (2002) of specimens of the genus Cryptops by Dugon \& ARThur (2012) and by BüCherL (1971). We observed this behavior among the three groups of specimens studied, although $O$. tibialis did not present morphologic characters (such as spines) that could suggest this behavior. At times, this behavior was associated with the use of all locomotory legs for restraining large prey, such as snakes and mice (see Fig. 5). For the capture of smaller individuals, centipedes kept the locomotory legs of the posterior two-thirds of their bodies attached to the substrate to ensure prey containment (G), as observed by Elzinga (1994).

Against small prey items, such as larvae of $Z$. morio, specimens of $S$. viridicornis performed only the capture behavior (C).

Table 1. Predatory behavior categories observed among the three centipede species studied in the experiment conducted in the Arthropods Laboratory of the Instituto Butantan (São Paulo, Brazil).

\begin{tabular}{|c|c|c|c|}
\hline Behavioral categories & Scolopendra viridicornis & Otostigmus tibialis & Cryptops iheringi \\
\hline $\begin{array}{l}\text { Antenna movement }(M) \text { - the extended antennae are raised and lowered repeatedly without touching the substrate } \\
\text { or the prey. }\end{array}$ & $x$ & $\mathrm{x}$ & $\mathrm{X}$ \\
\hline $\begin{array}{l}\text { Groping the substrate }(\mathrm{Ts}) \text { - the extended antennae are raised and lowered to touch the ground repeatedly, during } \\
\text { locomotion or when stationary. }\end{array}$ & $\mathrm{x}$ & $\mathrm{X}$ & $\mathrm{x}$ \\
\hline Groping the prey $(T p)$ - antennae are raised and lowered to touch the prey. & $x$ & $x$ & $x$ \\
\hline $\begin{array}{l}\text { Posture } 1(\mathrm{X} 1)-\text { the ultimate pair of legs is raised vertically. The elevation angle is directly proportional to the intensity } \\
\text { of the stimulus that triggered it. }\end{array}$ & $\mathrm{x}$ & $\mathrm{x}$ & $\mathrm{x}$ \\
\hline Raising (E) - centipede raises the first third of its body as the rest of the body remains adjacent to the substrate. & $\mathrm{x}$ & & \\
\hline Capture (C) - insertion of forcipules into prey. & $\mathrm{x}$ & $\mathrm{x}$ & $\mathrm{x}$ \\
\hline $\begin{array}{l}\text { Containment }(G) \text { - prey restraint along the ventral region of the first third of the body, with the aid of locomotory } \\
\text { legs. Legs of other segments are used as anchorage in the substrate. }\end{array}$ & $\mathrm{X}$ & & \\
\hline Onslaught (I) - displacement of the centipede toward the prey faster than the speed used in locomotion. & $\mathrm{x}$ & $\mathrm{x}$ & $\mathrm{x}$ \\
\hline Pinch (P) - lateral movement of the head and the ultimate pair of legs simultaneously converging toward the prey. & $\mathrm{x}$ & $\mathrm{x}$ & $\mathrm{x}$ \\
\hline $\begin{array}{l}\text { Transport }(S) \text { - the centipede restrains the prey along the ventral region of the first third of the body, assumes the } \\
\text { raising posture }(\mathrm{E}) \text {, and moves to another area of the terrarium. }\end{array}$ & $\mathrm{x}$ & $\mathrm{x}$ & $x$ \\
\hline Feeding $(A)$ - scraping movement of mouthparts on the prey. & $\mathrm{x}$ & $\mathrm{X}$ & $\mathrm{x}$ \\
\hline Scissor $(Z)$ - prey restraint with the ultimate pair of legs. & $\mathrm{x}$ & $\mathrm{X}$ & $\mathrm{x}$ \\
\hline $\begin{array}{l}\text { Locomotion }(C ̧) \text { - orderly movement of the legs, in which the animal's body is kept above ground and driven in a } \\
\text { certain direction. }\end{array}$ & $\mathrm{x}$ & $\mathrm{X}$ & $\mathrm{x}$ \\
\hline Antennae cleaning (La) - scraping movement of mouthparts on the antennae (from base to distal end). & $x$ & $\mathrm{x}$ & $x$ \\
\hline
\end{tabular}




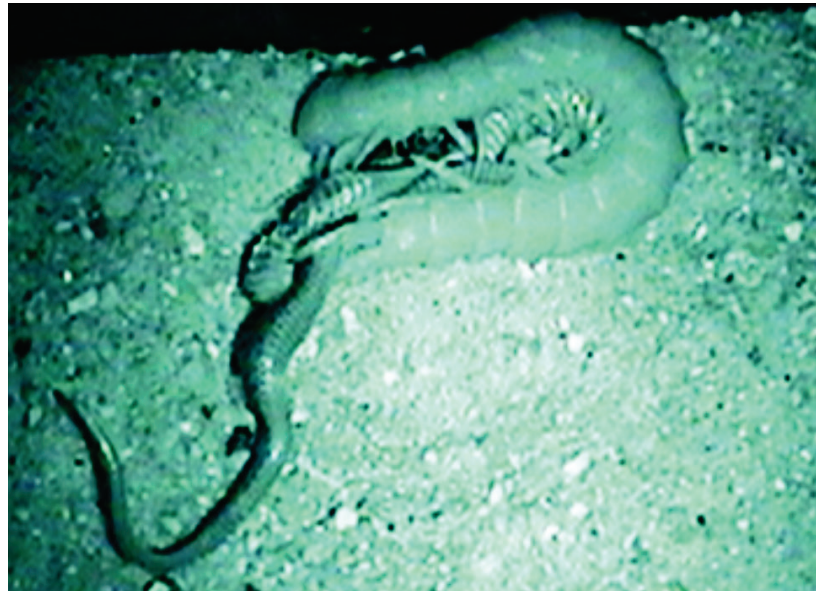

Figure 5. Image captured by video camera during predation by centipedes during experiments conducted to map and describe predatory behavior of three centipede species of the order Scolopendromorpha.

However, contact with beetles of this species induced the animals to rub prey several times against the substrate. This act may be related to the presence of spines on the legs of the beetles.

When confronting P. americana, insertion of the forcipules by the centipede on the cephalic region of the prey suggests a faster restraint behavior, according to the "venom optimization hypothesis" (WIGGER et al. 2002), also observed by Dugon \& ARTHUR (2012). While facing P. surinamensis and Blaberidae prey species, insertion of the forcipules always occurs in the ventral abdomen and thorax. Field observations by MoLINARI et al. (2005) indicate that specimens of Scolopendra gigantea Linnaeus, 1758 start the ingestion of prey preferably from the ventral portion of the individual, when preying upon bats. This choice may be related to the weakness of the surface of this body area, both in the adult insects used in the experiments and in small mammals.

The post-capture transport behavior (S) observed among the three groups of specimens studied depends on the predatory species and size of the prey. However, the frequency of occurrence of this behavioral category was low throughout the experiment. This behavior was more frequently observed during the regular feeding of animals in captivity, when natural light was used instead of artificial light in the experiment.

After each predatory sequence (successful or not), the centipedes meticulously cleaned their bodies. When confronting annelids, the cleaning behavior of the masticatory apparatus grew more intense, as they rubbed it several times against the substrate. This behavior may be related to the viscosity of the integument and the hemolymph of annelids.

One of our observations related to amphibians preyed upon by $S$. viridicornis specimens throughout this experiment confirms the behavior described by Carpenter \& Gillingham (1984), who reported abandonment of prey by the centipede after parotid gland drilling. After giving up the individual, the centipede adopted body-cleaning behavior (Lc) and wildly rubbed its masticatory apparatus, the cephalic plate and antennae against the substrate. However, another experiment related to amphibians resulted in the consumption of prey by the centipede, including the toxins contained in the parotid glands. In three other observations of $R$. crucifer individuals, the animals were groped (Tp) by the centipedes but not captured (C), possibly due to the centipedes recognizing the prey.

Posture 1 (X1) was observed in all centipede species tested right after the eliciting stimulus $(\mathrm{O})$, as also reported by KRONMÜLLER \& LewIS (2015), and preceded prey detection. Sensory perception employing the last pair of legs was reported by LewIs (1981, 2010), who suggested defensive and sensory functions of these appendages. SCHILEYKo (2002) also stated that scolopendromorphs present sharpened sensory perception in the last pair of legs. The behavior observed through the experiment suggests that posture 1 (X1) enhances the sensitivity of the last pair of legs.

The repeated behaviors of antennal movement $(\mathrm{M})$ and groping the substrate (Ts) and prey (Tp), associated with the size of the nervous lobes connected to antennae (JANGI 1966, LewIS 1981), may suggest that these structures are sensory receptors of the highest importance to centipedes.

According to SCHILEYKo (2002), centipedes forage actively for prey, in contrast to the sit-and-wait strategy of most arachnids. However, we observed that when prey touched the centipedes $(\mathrm{O})$, it triggered the predatory behavior sequence, suggesting that these myriapods also adopt the sit-and-wait capture strategy typical of opportunistic predators. Although this unexpected behavior of sitting-and-waiting was more common throughout the experiment, observations during the regular feeding of animals in captivity showed that active foraging was also adopted by individuals of $S$. viridicornis when detecting inert foods like raw meat fragments, dog food pellets, as well as fruits (apple, banana, pear) and compound foods (chocolate, cheese bread and milk pudding). Thus, we may suppose that despite the fact that centipedes adopted the sit-and-wait behavior more frequently during the experiments, these myriapods also search actively for food.

Volatilized substances from fruits or animals in decomposition can trigger the eliciting stimulus of active foraging. On the other hand, the sit-and-wait attitude appears to be linked to the capture of live animals. LewIs (1981) brought together reports of intake of fruits and vegetables by scolopendromorphs and geophilomorphs, but suggested that in the case of the latter this feeding option was related to the unavailability of prey. Observations during the regular feeding of animals in captivity prior to our experiment, when specimens of $S$. viridicornis detected foods like fruits and raw meat, allow us to suggest that the centipedes of the order Scolopendromorpha also include plant foods in their diet in the absence of animals as prey.

Studies by Cloudsley-Thompson $(1945,1952)$ indicate that the capture strategy adopted depends on the individual's satiety. When satiated, the adopted behavior is to sit-and-wait; when needing to feed, centipedes forage actively. 
A wide variety of feeding resources, aside from shelter during the hottest hours of the day to avoid dehydration, is essential for the survival of individuals in extreme natural environments such as "cerrado" and "caatinga" (Brazilian savanna). The sit-and-wait strategy benefits the survival of organisms, as it allows them to remain sheltered when satiated; then the predatory strategy switches to active foraging, and the animal behaves as a generalist in order to facilitate the search for food and ensure survival.

To subdue larger prey items such as mice, tarantula spiders, and snakes, specimens of $S$. viridicornis use more than one-third of their body to contain $(\mathrm{G})$ and restrain prey. The proportion of prey size to the centipede is the determining factor for the use of locomotory legs during retainment, as also noted by Elzinga (1994).

The absence of eyes induces $C$. iheringi to intense active foraging (Ç, Ts, Tp, and M) and the use of tactile and chemical stimuli to seek prey.

Otostigmus tibialis, which demonstrates fossorial habits, presented peculiarities in the scissor, pinch, onslaught, and capture behavioral categories compared to other genera. Individuals of this species were able to catch prey on the surface from their refuge.

Specimens of $S$. viridicornis prefer to use the first third of the body for prey capture and containment $(G)$. This behavior facilitates both containment and handling of larger prey items during the feeding process. As specimens of $O$. tibialis and $C$. iheringi prey on smaller animals, individuals of these two species do not adopt this behavior and use only their forcipules to contain prey.

The variety of active proteins contained in the venom of $S$. viridicornis (MALTA et al. 2008), as well as its size and most offensive behavior, favor a wider alimentary variety, including the intake of sizeable prey items. The biochemical properties of the venom of $O$. tibialis and $C$. iheringi, along with smaller body size, seem to be limiting factors to food diversity, but may indicate more specificity in their venom.

\section{FINAL CONSIDERATIONS}

Stating the implications of the predatory behavior categories that were observed in this study for a centipede phylogeny is very difficult because few studies on centipede behavior have been proposed so far. Reports on the predatory behavior of centipedes usually result from observations made in the field, especially of species from the genus Scolopendra (CLoudsLey-Thompson 1958, Carpenter \& Gillingham 1984, Molinari et al. 2005, Srbek-Araujo et al. 2012, Noronha et al. 2015). There are also some records of the geophilomorph Strigamia maritima Leach, 1817 (LewIs 1961) and the lithobiomorph Lithobius forficatus Linnaeus, 1758 (Plateaue 1878) that describe feeding methods; in both cases, the prey was seized with the forcipules, which held down the prey in conjunction with the first pairs of legs, the head and anterior end of the body being raised off the ground (LewIs 1981). The raising (E) and containment (G) categories seen in our experiment resemble the feeding behavior described by LEWIS (1961) and Plateaue (1878) regarding geophilomorphs and lithobiomorphs, respectively. Therefore, these feeding behaviors could represent a character supporting Pleurostigmophora; however, the feeding mechanism of Craterostigmomophora is still unknown. Furthermore, the raising (E) and containment (G) categories were not observed in $O$. tibialis and $C$. iheringi, both scolopendromorphs as well. The predatory behavior of centipedes must be further investigated in order to better understand the evolution of the group.

\section{ACKNOWLEDGMENTS}

This paper was supported by Fundação de Amparo à Pesquisa do Estado de São Paulo (FAPESP process 2003/045271) and Instituto Nacional de Ciência e Tecnologia em Toxinas - INCTTOX. Katia C. Barbaro was supported by a grant from Conselho Nacional de Desenvolvimento Científico e Tecnológico (CNPq process 305719/2013-0).

\section{LITERATURE CITED}

Bonato L, Chagas-Junior A, Edgecombe GD, Lewis JGE, Minelli A, Pereira LA, Shelley RM, Stoev P, Zapparoli M (2016) ChiloBase 2.0 - A World Catalogue of Centipedes (Chilopoda). Available online at: http://chilobase.biologia.unipd.it [Accessed 09/04/2016]

BÜCHERL W (1971) Venomous chilopods or centipedes, p. 169196. In: BÜCHERL W, BuCKLEY EE (Eds.) Venomous animals and their venoms 3. New York, Academic Press.

Carpenter CC, Gillingham JC (1984) Giant Centiped (Scolopendra alternans) Atacks Marine Toad (Bufo marinus). Caribean Journal of Science 20: 71-72.

Cloudsley-Thompson JL (1945) Behaviour of the common centipede Lithobius forficatus. Nature 156: 537-538.

Cloudsley-Thompson JL (1952) The behaviour of centipedes and millipedes. I. Responses to environmental stimuli. The Annals and Magazine of Natural History 5: 417-434.

Cloudsley-Thompson JL (1955) Some aspects of the biology of centipedes and scorpions. Naturalist 6: 147-153.

Cloudsley-Thompson JL (1958) Spiders, scorpions, centipedes and mites. London, Pergamon, 228p.

Cumming WD (1903) The food and poison of a centipede. The Journal of the Bombay Natural History Society 15: 364-365.

Dugon MM, Arthur W (2012) Prey orientation and the role of venom availability in the predatory behavior of the centipede Scolopendra subspinipes mutilans (Arthropoda: Chilopoda). Journal of Insect Physiology 58: 874-880. doi: 10.1016/j. jinsphys.2012.03.014

ElzINGA RJ (1994) The use of legs as grasping structures during pray capture and feeding by the centipede Scolopendra viridis 
Say (Chilopoda: scolopendridae). Journal of Kansas Entomologial Society 67: 369-372.

JANGI BS (1966) Scolopendra (the Indian centipede). The Indian Zoological Memoirs. Calcutta, The Zoological Society of India, 109p.

Japyassú HF, AlberTs CC, Izar P, SAto T (2006) EthoSeq: a tool for phylogenetic analysis and mining on behavioural sequences. Behavior Research Methods 38: 549-556.

Knysak I, Martins R, Bertim CR, Wen FH (1994) Lacraias de importância médica no estado de São Paulo: biologia e aspectos epidemiológicos. São Paulo, Centro de Vigilância Epidemiológica, Secretaria de Estado da Saúde, 4p.

KnYsak I, Martins R, Bertim CR (1999) Epidemiological aspects by centipede bite (Scolopendromorpha: Chilopoda) registered in the Greater São Paulo, SP, Brasil. Revista de Saúde Pública 31: $514-518$.

KronMÜLler C, LEWIS JGE (2015) On the function of the ultimate legs of some Scolopendridae (Chilopoda, Scolopendromorpha). In: Tuf IH, Tajovskŕ K (Eds.) Proceedings of the 16th International Congress of Myriapodology, Olomouc, Czech Republic. ZooKeys 510: 269-278. doi: 10.3897/zookeys. 510.8674

LEwIS JGE (1961) The life history and ecology of the littoral centipede Strigamia Maritima (Leach). Proceedings of the Zoological Society of London 137: 221-247.

LewIS JGE (1981) The Biology of Centipedes. Cambridge, Cambridge University Press, 474p.

LEWIS JGE (2010) On the function of the ultimate legs in Cryptops and Theatops (Chilopoda: Scolopendromorpha). International Journal of Myriapodology 3: 145-151. doi: 10.1163/187 $525410 X 12578602960542$

Malta MB, Lira MS, Soares SL, Rocha GC, Knysak I, Martins R, Guizze SPG, Santoro ML, Barbaro KC (2008) Toxic Activities of Brazilian Centipede Venoms. Toxicon 52: 255-263. doi: 10.1016/j.toxicon.2008.05.012

Manton SM (1964) Mandibular mechanisms and the evolution of arthropods. Philosophical Transaction of Royal Society, Series B, 247: 1-183.

Medeiros Cr, Susaki TT, Knysak I, Cardoso Jl, Málaque CM, Fan HW, Santoro ML, França FO, Barbaro KC (2008) Epidemiologic and clinical survey of victims of centipede stings admitted to Hospital Vital Brazil (São Paulo, Brazil). Toxicon 52: 606-610. doi: 10.1016/j.toxicon.2008.07.009
Misra PL (1942) On the life history of a new gregarine, Grebneckiella patellae sp. nov. from the centipede Scolopendra morsitans Linn., with a note on the family Dactylophoridae Lèger, 1892. Records of the Indian Museum 44: 323-337.

Molinari J, Gutiérrez EE, Ascenção AA, Nassar JM, Arends A, MÁrquesz RJ (2005) Predation by giant centipedes, Scolopendra gigantea, on three species of bats in a venezuelan cave. Caribbean Journal of Science 41: 340-346.

Noronha JC, Battirola LD, Chagas-Júnior A, Miranda RM, CarPANEDo RS, Rodrigues DJ (2015) Predation of bat (Molossus molossus: Molossidae) by the centipede Scolopendra viridicornis (Scolopendridae) in Southern Amazonia. Acta Amazonica 45: 333-336.

OKEDEN WP (1903) A centipede eating a snake. The Journal of the Bombay Natural History Society 15: 1 .

Plateau F (1878) Recherche sur les phénomènes de la digestion et sur la structure de l'appareil digestif chez les Myriapodes de Belgique. Académie royale des Sciences, des Lettres et des Beaux-Arts de Belgique 42: 1-91.

Schileyko AA (2002) Scolopendromorpha, p. 479-500. In: AdIs J (Ed.) Amazonian Arachnida and Myriapoda. Moscow, Pensoft, 596p.

Srbek-Araujo AC, Nogueira MR, Lima IP, Peracchi AL (2012) Predation by centipede Scolopendra viridicornis (Scolopendromorpha, Scolopendridae) on roof-roosting bats in the Atlantic Forest of southeastern Brazil. Chiroptera Neotropical 18: 1128-1131.

Wigger E, Kunn-Nentwig L, Nentwig W (2002) The venom optimization hypothesis: a spider injects large venom quantities only into difficult prey types. Toxicon 40: 749-752.

Submitted: 12 February 2016

Received in revised form: 2 June, 2016

Accepted: 11 July 2016

Editorial responsibility: Ricardo Pinto da Rocha

Author Contributions: SPGG and IK designed the experiments; SPGG conducted the experiments; KCB revised the manuscript; MK, AC and SPGG analysed the data and wrote the paper. Competing Interests: The authors have declared that no competing interests exist. 